\title{
Rhizobacteria-mediated Induced Systemic Resistance in Cucumber Plants against Anthracnose Disease Caused by Colletotrichum orbiculare
}

\author{
Yong-Chull Jeun*, Yun-Jeong Lee ${ }^{1}$ and Yeoung-Seuk Bae ${ }^{2}$ \\ Department of Plant Resource Science, the Research Institute for Subtropical Agriculture and Biotechnology, Cheju National \\ University, Jeju 690-756, Korea \\ ${ }^{\prime}$ Plant Nutrition Division, ${ }^{2}$ Plant Pathology Division, National Institute of Agricultural Science and Technology, RDA, Suwon 441- \\ 707, Korea
}

(Received on March 7, 2004; Accepted on July 27, 2004)

\begin{abstract}
Bacterial isolates TRL2-3 and TRK2-2 showing antifungal activity in vitro test against some plant pathogens were identified as Pseudomonas putida and Micrococcus luteus, respectively. Pre-treatment with both bacterial isolates at the concentration $1.0 \times 10^{7}$ and $10^{6} \mathrm{cfu} / \mathrm{ml}$ in the rhizosphere could trigger induced systemic resistance in the aerial part of cucumber plants against anthracnose caused by Colletotrichum orbiculare. However, the pre-treatment with the higher concentration at $1.0 \times 10^{8} \mathrm{cfu} / \mathrm{ml}$ of both isolates could not induce resistance after challenge inoculation with $C$. orbiculare. As a positive control, the treatment with DL-3 amino butyric acid caused a remarkable reduction of disease severity whereas the lesions on the leaves of untreated plants developed apparently after the fungal inoculation. From these results, it was recomended that disease control using both bacterial isolates inducing systemic resistance in the field where chemical application is forbid.
\end{abstract}

Keywords : Antifungal activity, Colletotrichum orbiculare, Cucumber, Induced systemic resistance, Plant growth promoting rhizobacteria (PGPR)

Many microorganisms have been studied for plant protection against plant pathogens for many years (Handelsman and Stabb, 1996; van Lenteren, 1995). Abundant antagonists have successfully control plant diseases in greenhouse trials, whereas field application seems to be less successful (Rovira and Davey, 1974).

An alternative strategy for plant protection is using a systemic induced resistance on crops, which can be triggered by pre-inoculation of plant growth promoting rhizobacteria (PGPR, van Loon et al., 1998a). The PGPRmediated resistance has been defined as induced systemic resistance (ISR, van Loon et al., 1998a). The treatment with

\footnotetext{
*Corresponding author.

Phone) +82-64-754-3319, FAX) +82-64-725-2351

E-mail)ycjeun@cheju.ac.kr
}

PGPR may activate the endogenous defense mechanism resulting in the expression of systemic resistance on the aerial part of the plants (van Loon et al., 1998a). Moreover, for the expression of resistance the PGPR is not required to contact with plant pathogens directly and the PGPR can grow well in the rhizosphere of the plant. Therefore, the application of PGPR is one of the possible strategies for plant protection in the field (van Loon et al., 1998a).

ISR is differentiated from systemic acquired resistance (SAR), which is induced by pre-treatment with plant pathogen or chemical activator (Pieterse et al., 1998). PGPR enhance the growth of plant and most of them have a direct anti-fungal activity, whereas plant pathogens or chemical activators have not (Jeun et al., 2001). Furthermore, ISR can be triggered in the plants without accumulation of salicylic acid (SA), which is obligatorily necessary for expression of SAR by pathogens or some activators (Pieterse et al., 1996). Pieterse et al. (1996) found that the signal mechanism of ISR is different from those of SAR using transgenic plants. They were also shown that jasmonic acid and ethylene might involve to the resistance signal in arabidopsis after pre-inoculated with PGPR. The expression of resistance may also be different between SAR and ISR (Sticher et al., 1997; van Loon et al., 1998a). For example, the pathogenesis related protein (PR-protein) has been known as one of the important resistance factors for the expression of SAR in many plants (Sticher et al., 1997), whereas the PR-protein was not found in arabidopsis plants expressing ISR (van Loon et al., 1998a).

In the previous study bacterial strains were isolated from the rhizosphere of the plant growing in Jeju and were tested for anti-fungal activities of the isolates against several plant pathogens (Lee et al., 2003). In this study the selected bacterial isolates TRL2-3 and TRK2-2 were pre-inoculated in the rhizosphere of cucumber plants following the challenge inoculation with anthracnose pathogen $C$. orbiculare. Aim for the selection of an effective ISR inducing agent the efficacy of the selected isolates for induced systemic resistance was determined. 


\section{Materials and Methods}

Identification of rhizosphrial bacteria. To identify the selected rhizobactera, TRK2-2 and TRL2-3 were cultured on tryptic soy agar (TSA) and Biolog Universal Growth Medium (BUGM ${ }^{\mathrm{TM}}$, Biolog, Inc.) at $28^{\circ} \mathrm{C}$ for $24 \mathrm{hr}$., respectively. Then, each isolate was identified according to manufacturers manual by fatty acid anaylsis (Sherlock microbial identification system, MIDI, Inc.) and Biolog MicroLog3 system (Biolog, Inc.).

Plants. Cucumber seeds (Cucumis sativus L. cv. Eun Sung) were sown in a plastic pot ( 72 holes, $4 \mathrm{~cm}$ diameter each) filled with commercial soil (Choroc Nala ${ }^{\circledR}$, Bokyung Nongsang, Korea) containing $10 \%$ of perlite (Parat ${ }^{\otimes}$ Sam Son, Korea). Cucumber seedlings were grown in a greenhouse maintaining $28^{\circ} \mathrm{C}$ at daytime and $25^{\circ} \mathrm{C}$ at night. Plants were watered about $30 \mathrm{ml}$ per plant once every day.

Treatment of bacterial isolates in the plants for triggering of ISR. TRL2-3 and TRK2-2 among the bacterial isolates showing antifungal activity were selected for test of triggering of ISR in cucumber plants. Both strains were grown in tryptic soy agar at $28^{\circ} \mathrm{C}$ for $24 \mathrm{~h}$. The concentration of each bacterial strain was adjusted to $1.0 \times 10^{8}, 1.0 \times 10^{7}$ and $1.0 \times 10^{6}$ colony forming unit (cfu) $/ \mathrm{ml}$ according to the methods described by Park and Kloepper (2000). Thirty $\mathrm{ml}$ of each bacterial suspension was soildrenched around each cucumber plant 7 days before challenge of C. orbiculare. Distilled water as negative control was drenched around the cucumber plants instead of the bacterial suspension.
Thirty $\mathrm{ml}$ of DL-3-amino butyric acid (BABA; 1 and $10 \mathrm{mM}$, respectively) was drenched in the soil for triggering SAR 3 days before the fungal inoculation. The BABA treated plants were used as a positive control.

Challenge inoculation with anthracnose pathogen. Anthracnose pathogen, Colletotrichum orbiculare was grown in green bean agar medium for 5 days. Ten $\mathrm{ml}$ distilled water was poured in the medium grown the anthracnose pathogen and than the fungal conidia were harvested using a brush. The conidial concentration was adjusted to $2.5 \times 10^{5}$ conidia/ml. The conidial suspension added with $100 \mu \mathrm{l} / \mathrm{l}$ tween 20 , which enhances the adhesion of conidia on leaf surface, was used as inoculum for challenge inoculation on cucumber leaves.

The conidial suspension of $C$. orbiculare was sprayed on the aerial cucumber leaves 3 days after treatment of the bacterial suspension. The plants inoculated with the conidial suspension of the pathogen were kept in a humid chamber maintaining $100 \% \mathrm{RH}$ for $24 \mathrm{~h}$ and then transferred to the greenhouse at $28^{\circ} \mathrm{C}$ during the day and $25^{\circ} \mathrm{C}$ at night with $60 \%$ humidity.

Evaluation of resistance. Disease severity on the inoculated leaves was determined 5 days after challenge-inoculation by visual estimating the leaf area occupied by anthracnose lesion. Protection efficacy against the disease was calculated according to Cohen (1994) described as protection $(\%)=100(1-\mathrm{x} / \mathrm{y})$ in which $\mathrm{x}$ and $\mathrm{y}$ are disease severity values in treated and control plants after challenge inoculation, respectively. The data of disease severity were statistically analyzed in both bacterial isolates and

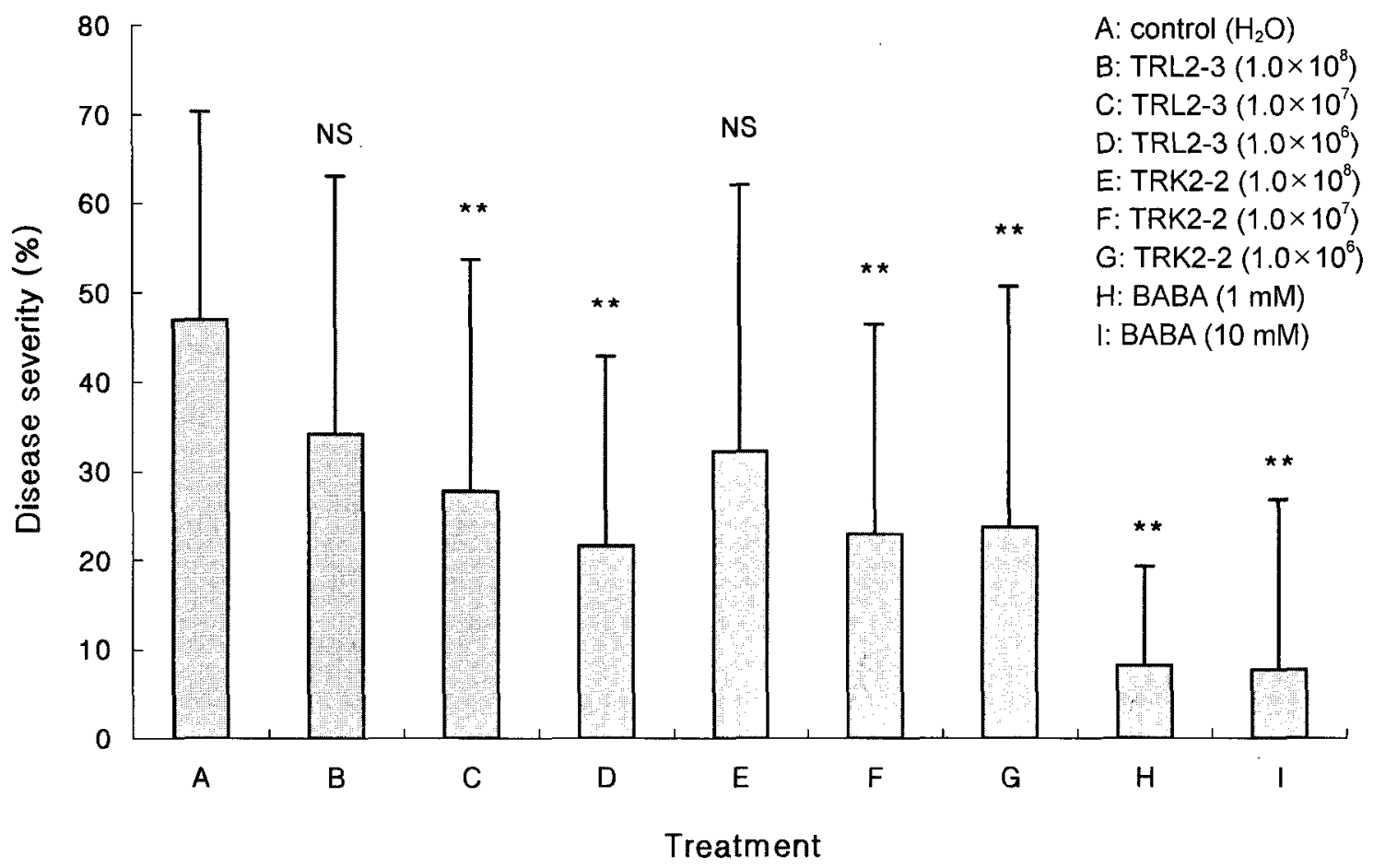

Fig. 1. Induction of systemically induced resistance in cucumber plants against anthracnose disease 7 days after inoculation with Colletotrichum orbiculare $\left(1.0 \times 10^{5}\right.$ conidia/ml). The presented plants were untreated control $(\mathbf{A})$, pre-treated with $30 \mathrm{ml}$ of bacterial suspension of TRL2-3 and TRK2-2 (both $1.0 \times 10^{6} \mathrm{cfu} / \mathrm{ml}$ ) (B and C), and DL-3-anmino butyric acid (BABA; $\left.10 \mathrm{mM}\right)(\mathrm{D}) 5$ days before the challenge inoculation. 
BABA pre-treated and the non-treated plants using a paired $t$-test. Significance levels at $P=0.001$ was used for all statistical tests.

\section{Results}

The bacterial isolates TRK2-2 and TRL2-3, which showed a strong anti-fungal activity in vitro test (Lee et al., 2003), were identified as Micrococcus luteus and Pseudomonas putida biotype B by Biolog system, respectively. Both bacterial isolates were selected in order to determine their resistance efficiencies against cucumber anthracnose caused by $C$. orbiculare. The anthracnose lesion caused by $C$. orbiculare was well developed on the leaves of cucumber plants untreated control after inoculation with Colletotrichum orbiculare and the disease severity was about $48 \%$ at 5 days (Fig. 2). The lesion developed further and the leaves was almost died 2 days later (Fig. 1A). However, when the bacterial isolate TRL2-3 was pre-treated with the low concentration $\left(1.0 \times 10^{6} \mathrm{cfu} / \mathrm{ml}\right)$, the lesion development was limited at the infected sites on the leaves (Fig. 1B)
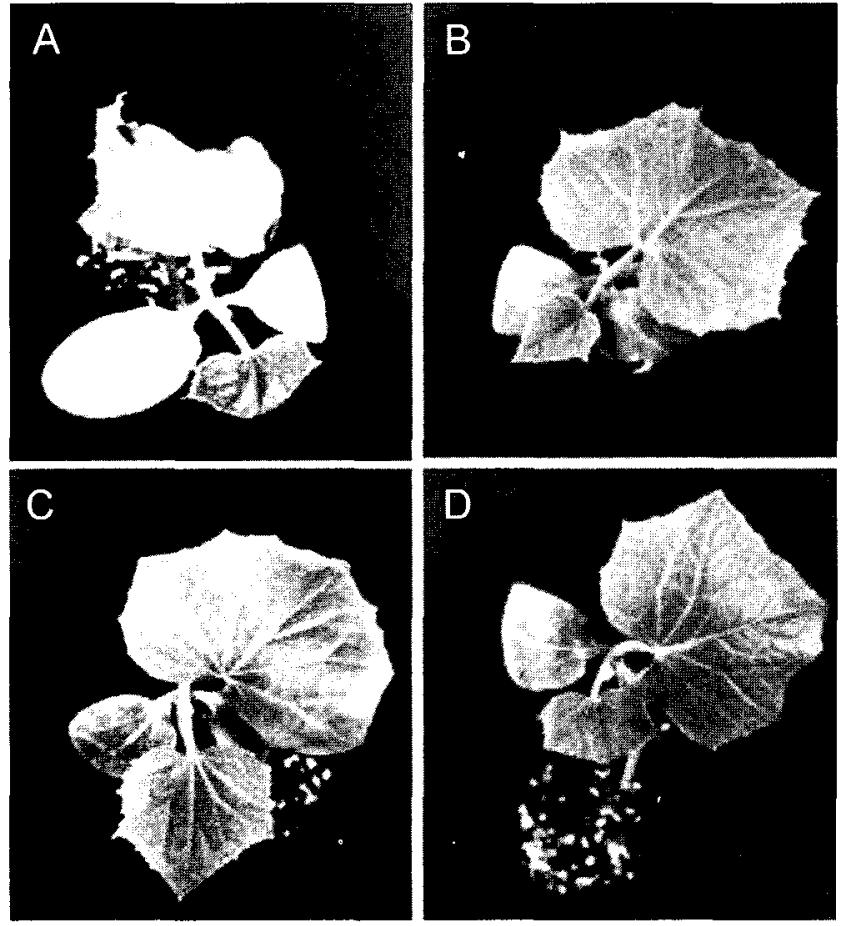

Fig. 2. Disease severity on the leaves of cucumber plants pretreated with different concentration of bacterial isolates TRL2-3, TRK2-2, DL-3-anmino butyric acid (BABA), and non-treated after inoculation with $C$. orbiculare $\left(2.5 \times 10^{5}\right.$ conidia/ml). The disease severities were measured at 5 days after challenge inoculation. The vertical bars indicate the standard deviation of the three separated experiments each containing 6 plants "per treatment.

ns $=$ non significant

$* *=$ significant at the $0.1 \%$ probability level by T-test
Table 1. Protection rates of anthracnose caused by $C$. orbiculare by the treatment of selected bacterial isolates (TRL2-3 and TRK22) and DL-3-anmino butyric acid (BABA) in cucumber plants

\begin{tabular}{lccccc}
\hline \hline \multirow{2}{*}{ Treatment } & \multicolumn{3}{c}{ Protection rate of anthracnose $(\%)^{\mathrm{a}}$} \\
& $\begin{array}{c}\text { Concentration of bacterial } \\
\text { suspension }(\mathrm{cfu} / \mathrm{ml})\end{array}$ & \multicolumn{2}{c}{$\begin{array}{c}\text { Concentration of } \\
\text { BABA }(\mathrm{mM})\end{array}$} \\
\cline { 2 - 6 } \cline { 3 - 6 } TRL2-3 & $1.0 \times 10^{8}$ & $1.0 \times 10^{7}$ & $1.0 \times 10^{6}$ & & 10 \\
TRK2-2 & 27.2 & 40.9 & 54.0 & - & - \\
BABA & 31.5 & 51.3 & 49.6 & - & - \\
\hline
\end{tabular}

${ }^{\circ}$ Protection rate $(\%)=(1-($ lesion number on the leaves treated plants $)$ lesion number on the leaves non-treated plants) $) \times 100$

resulting in significantly reduced disease development compared to the control (Fig. 2) with $54 \%$ of disease protection efficacy (Table 1). Similarly, TRK2-2 could induce the systemic resistance at low concentration (Fig. 1C and 2). Both isolates TRL2-3 and TRK2-2 could decrease the disease severity at the concentration with $1.0 \times 10^{7} \mathrm{cfu} / \mathrm{ml}$ (Fig. 2) resulting in protection efficacy of the disease at 40.9 and $51.3 \%$, respectively (Table 1 ). However, both isolates with high concentration $\left(1.0 \times 10^{8} \mathrm{cfu} / \mathrm{ml}\right)$ could protect the plants only about $30 \%$ against anthracnose disease and the reduction of disease was not statistically significant (Fig. 2 and Table 1). The treatment with DL-3-amino butyric acid, which was used as a positive control, caused the remarkable reduction of disease severity and the high protection against anthracnose at the concentration of 1 or $10 \mathrm{mM}$ (Fig. 2 and Table 1).

\section{Discussion}

Because using the antagonistic microorganisms to control of plant diseases has not been always successful in the field, new strategy of the biological control such as using crops expressing an induced systemic resistance (ISR) has been looking for control plant diseases (van Loon et al., 1998a). It may be resulted in reduction of chemical application in the field. In this study to select an effective microorganism inducing ISR against plant diseases, the selected rhizobacteria showing antifungal activity were tested with cucumber- $C$. orbiculare interaction system.

Selected bacterial isolate TRL2-3 and TRK2-2 were identified as Pseudomonas putida biotype B (similarity at 0.547 ) by Biology system and Micrococcus luteus (similarity at 0.779 ) by fatty acid anaysis. It seems to be a certain concentration of PGPR to begin triggering of ISR in plants. Some PGPR strains such as Serratia marcescens or Pseudomonas fluorescens could effectively induce systemic resistance in cucumber plants against anthracnose disease at certain concentration (Liu et al., 1995). In this study, we 
found that ISR could not be effectively triggered when both bacterial isolates were pre-treated with relatively high concentration (Fig. 2). But the treatments with lower concentration of both isolates were resulted in the significant reduction of disease severity (Fig. 2). There is no clear explaining to the reasons why the bacteria cannot trigger ISR at high concentration.

The mechanisms of ISR have been compared with those of systemic acquired resistance (SAR, Jeun et al., 2004), which has been studied in many ways (Sticher et al., 1997). In contrast to SAR, some PGPR strains mediating systemic resistance have direct antifungal activity. In our previous study both bacterial isolates showed direct antifungal effect in vitro test (Lee et al., 2003). Another mechanism of expression of ISR is competition mineral element such as ion (Fe), which is easily captured by siderophores produced in PGPR (Maurhofer et al., 1994; Van Loon et al., 1997; 1998 b). Contrasts, the resistance expression by competition of nutrient have not been reported in the plants expressing SAR. The other resistance mechanisms of ISR, however, seem to be similar with those of SAR, which is involved in the resistant gene $n p r l$ (Pieterse and van Loon, 1999).

DL-3 amino butyric acid (BABA) is well known as an activator triggering SAR in many plants (Cohen, 2002; Jeun and Park, 2003; Zimmerli et al., 2000). In this study BABA could effectively induce systemic resistance showing as a positive control (Fig. 1 and 2). Also untreated plants as a negative control showed a high severity compared with the treated plants (Fig. 1 and 2). These controls clearly revealed that the pre-treatments of both bacterial isolates with a certain concentration could induce systemic resistance.

In summary, the bacterial isolates TRL2-3 and TRK2-2 could trigger ISR in cucumber plants against anthracnose disease. Although the ISR by both isolates were not higher compared to those of SAR by BABA, it is suggested that the protection by using microorganism may be useful in the field or a certain condition, for example, where chemical application is forbid. For this purpose, more research concerning ISR should be carried out.

\section{Acknowledgement}

This work was supported by Agricultural R\&D Promotion Center (ARPC).

\section{References}

Cohen, Y. 1994. 3-aminobutyric acid induces systemic resistance against Peronospore tabacina. Physiol. Mol. Plant Pathol. 44:273-288.

Cohen, Y. R. 2002. $\beta$-aminobutyric acid-induced resistance against plant pathogens. Plant Dis. 86:448-457.
Handelsman, J. and Stabb, E. V. 1996. Biocontrol of soilborne plant pathogens. Plant Cell 8:1855-1869.

Jeun, Y. C. and Park, E. W. 2003. Ultrastructures of the Leaves of Cucumber Plants Treated with DL-3-Aminobutyric Acid at the Vascular Bundle and the Penetration Sites after Inoculation with Colletotrichum orbiculare. Plant Pathol. J. 19:85-91.

Jeun, Y. C., Park, K. S., Kim, C. H., Fowler, W. D. and Kloepper, J. W. 2004. Cytological Observations of Cucumber Plants During Induced Resistance Elicited by Rhizobacteria. Biol. control 29:34-42.

Jeun, Y. C., Park, K. S. and Kim, C. H. 2001. Different mechanisms of induced systemic resistance (ISR) and systemic acquired resistance (SAR) against Colletotrichum orbiculare on the leaves of cucumber plants. Mycobiology 29:19-26.

Lee, C. S., Kim, K. D., Hyun, J. W. and Jeun, Y. C. 2003. Isolation of Rhizobacteria in Jeju Island showing anti-fungal effect against various plant pathogens. Microbiology In press.

Liu, L., Kloepper, J. W. and Tuzun, S. 1995. Induction of systemic resistance in cucumber by plant growth-promoting rhizobacteria: Duration of protection and effect of host resistance on protection and root colonization. Phytopathology 85:1064-1068.

Maurhofer, M., Hase, C., Meuwly, P., Mraux, J-P. and Defago, G. 1994. Induction of systemic resistance of tobacco to tobacco necrosis virus by the root-colonizing Pseudomonas fluorescens strain CHAO: influence of the gacA-gene and of pyoverdine production. Phytopathology 84:139-146.

Park, K. S. and Kloepper, J. W. 2000. Activation of PR-1a promoter by rhizobacteria that induce systemic resistance in tobacco against Pseudomonas syringae pv. tabaci. Biol. Control 18:2-9.

Pieterse, C. M. J. and Van Loon, L. C. 1999. Salicylic acid-independent plant defence pathways. Trends Plant Sci. 4:52-58.

Pieterse, C. M. J., Van Wees, S. C. M., Hoffland, E., Van Pelt, J. A. and Van Loon, L. C. 1996. Systemic resistance in Arabidopsis induced by biocontrol bacteria is independent of salicylic acid accumulation and pathogenesis-related gene expression. Plant Cell 8:1225-1237.

Pieterse, C. M. J., Van Wees, S. C. M., Van Pelt, J. A., Knoester, M., Laan, R., Gerrits, H., Weisbeek, P. J. and Van Loon, L. C. 1998. A novel signaling pathway controlling induced systemic resistance in Arabidopsis. Plant Cell 10:1571-1580.

Rovira, A. D. and Davey, C. B. 1974. Bioliogy of the rhizosphere. In The Plant Root and its Environment, E. W. Carson (ed.). University Press of Virginia, pp. 153-204.

Sticher, L., Mauch-Mani, B. and Métraux, J. P. 1997. Systemic acquired resistance. Annu. Rev. Phytopathol. 35:235-270.

Van Loon, L. C., Bakker, P. A. H. M. and Pieterse, C. M. J. 1997. Mechanisms of PGPR-induced resistance against pathogens. In: Ogoshi, A., Kobayashi, Y., Homma, Y., Kodama, F., Kondo, N. and Akino, S. eds. Plant Growth-Promoting Rhizobacteria-Present status and future prospects. Sapporo: OECD, pp. 50-57.

Van Loon, L. C., Bakker, P. A. H. M. and Pieterse, C. M. J. 1998 a. Systemic resistance induced by rhizosphere bacteria. Annu. Rev. Phytopathol. 36:453-483.

Van Loon, L. C., Bakker, P. A. H. M. and Pieterse, C. M. J. 1998 b. 
Induction and expression of PGPR-mediated induced resistance against pathogens. In: Duffy, B., Rosenberger, U. and Defago, G. eds. Molecular Approaches in Biological Control. Delemont: IOBC/OILB, pp. 103-110.
Zimmerli, L., Jakab, G., Métraux, J. P. and Mauch-Mani, B. 2000. Potentiation of pathogen-specific defense mechanisms in Arabidopsis by $\beta$-aminobutyric acid. Proc. Natl. Acad. Sci. USA 97:12920-12925. 